\title{
Adriaan Reland's Fascination with the Languages of the World
}

\author{
Toon van Hal
}

Adriaan Reland has often been described as a scholar endowed with an adventurous mind, but with a body that was tied and chained to his desk. ${ }^{1}$ His linguistic skills were truly remarkable, and led one of his former teachers to declare him 'the miracle of his years'. ${ }^{2}$ When this statement was published, Reland was barely fourteen years old. Today, Adriaan Reland owes his renown first and foremost to his mastery of the classical and so-called Oriental languages - the Early Modern designation for what are now generally known as the 'Semitic languages', but also including Persian and Ottoman Turkish. It is, therefore, mostly for these reasons that Reland is widely praised, as for instance in Diderot's famous Encyclopédie, where the entry 'Rijp' — a village between Alkmaar and Purmerend - is devoted to Reland in its entirety: 'This village is of no significance; but it boasts of having given birth to Hadrian Reland, a scholar of vast erudition'3 ${ }^{3}$ And also in Edward Gibbon's (1737-1794) voluminous masterwork, The History of the Decline and Fall of the Roman Empire, Reland is frequently quoted for similar reasons and with great respect. It is, however, important to note that his interest in foreign languages went far beyond his command of the classical and the Oriental languages, as can easily be inferred from his very rich manuscript catalogue, including a considerable number of non-European manuscripts. ${ }^{4}$ This chapter will investigate the backdrop against which his exceptional interest in 'less evident' languages can be understood. After briefly outlining the attitudes towards language learning that were in vogue in the Early Modern period, the article will examine where, why and how Reland contributed to the mapping of the world's languages.

1 I am indebted to Reuben Pitts, who revised the English, the editors of this volume and two anonymous reviewers.

2 Van der Hooght, Lexicon Novi Testamenti, voor-reden (unnumbered).

3 'Ce village n’a rien de considérable; mais il se glorifie d'avoir donné la naissance à Reland l'Adrien, savant d'une vaste érudition'. See De Jaucourt, 'Ryp' (1765), p. $45^{\circ}$.

4 See the contributions by Bart Jaski and Arnoud Vrolijk in this volume. 


\section{$1 \quad$ Language Learning in the Early Modern Period: Do's and Don'ts}

Joseph Serrurier (1663-1742), a professor of medicine, delivered an extensive funerary oration after Reland's death. Of Reland's command of languages he said the following:

He was very well aware that the learned languages are instruments for the arts and sciences, and that only the sciences and the liberal arts can equip and enrich the mind. Thus, he studied Greek and Latin, as well as all those Oriental languages that were in some way connected to erudition. He did not do this in order to wallow in idle arrogance or to hold others in haughty contempt-in contrast to some men who excel in this kind of emptiness. Nor did he learn these languages in order to improve his language skills only, in complete isolation from all genuine learning and discipline of wisdom, or in order to obtain the faculty of speaking them purely and faultlessly. But he did so in order to allow his mind, by much reading, to imbibe all kinds of hidden knowledge, and in order to be able to speak and write with both pure and appropriate words about the most significant affairs. ${ }^{5}$

In other words, Serrurier claimed that Reland had been studying languages for valid reasons, and that there were also many scholars who learned languages for the wrong reasons. Serrurier's attitude towards language learning was widespread in the Early Modern period. More than fifty years earlier, bishop Brian Walton (160o-1661) asserted that

languages are just peels, yet cognition of things itself is the kernel. We do not learn languages as a goal in itself, but for something else. Whoever limits himself to languages resembles a man halting in the arcades of a house, without entering it and without seeing its interior. ${ }^{6}$

5 'Probe noverat eruditas linguas artium et scientiarum instrumenta esse, scientias vero solas et liberales artes animum ornare et perficere. Graecam igitur linguam et Latinam, omnesque Orientales, quibus aliqua eruditionis pars continetur, perdidicit, non ut inani fastu turgens alios superbe contemneret, quae quorumdam hominum vanitas est, neque ut ab omni ingenua doctrina et sapientiae disciplina vacuus sermonem tantum suum locupletaret, aut emendate et pure loquendi solam facultatem sibi compararet; verum ut pectus suum multa legendo omni reconditiori scientia expleret, ut puris quoque propriisque verbis de rebus gravissimis dicere et scribere posset', Serrurier, 'Oratio funebris', p. 32.

6 'linguae enim putamina sunt, nucleus vero est ipsa rerum cognitio. Nec linguas propter se, sed propter aliud addiscimus. Qui vero in linguis haerent, similes sunt iis, qui in porticu subsistunt, in domum vero non intrant, nec eius penetralia vident', Walton, 'De linguarum 
And more than fifty years later, we see how the purely ancillary position of language studies is still defended even by the man whom many textbooks style as the founder of modern linguistics. In a letter written in 1784, William Jones stated that he had always regarded 'languages as the mere instruments of real learning', and that it would be improper to confuse them 'with learning itself'? Although not every Early Modern scholar would have supported this assessment, it is safe to say that it was a widespread topos from the sixteenth to the eighteenth centuries. But if Serrurier was right that Reland only invested in languages for solely instrumental reasons, how can we explain his interest in remote Oriental and Occidental languages, many of which had no tradition in writing (and hence in learning)?

In one of his anonymous anti-dogmatic dissertations, which generated such outrage that their editor Gotthold Ephraim Lessing (1729-1781) ended up losing his censorship privileges, ${ }^{8}$ Hermann Samuel Reimarus (1694-1768) argued that it was impossible for all human beings on earth to reasonably believe in Revelation. Relying on Reland's observation that in one Mexican province alone more than ten different languages were spoken, and referring to the very great number of languages included in John Chamberlayne's Lord's Prayer collection, even though that was considered to be outdated, Reimarus concluded that the 'multiplicity of languages remains, therefore, an insurmountable difficulty in spreading the Revelation or in disseminating Christianity. When will we see the Bible translated and printed in 500 languages?'9 $T$ To answer Reimarus's question: several Early Modern missionaries had already taken up this challenge, and their efforts are continued by present-day missionaries, such as the somewhat controversial Summer Institute of Linguistics. ${ }^{10}$ But

natura', p. 218. See also Bibliander, De ratione communi omnium linguarum et literarum commentarius, p. 42; Hayne, Linguarum cognatio seu De linguis, p. 64; praefatio.

$7 \quad$ Quoted after Raj, Relocating Modern Science, p. 122.

8 Groetsch, Hermann Samuel Reimarus (1694-1768), pp. 3-4.

9 'Demnach bleibt die Vielheit der Sprachen eine unüberwindliche Schwierigkeit in der Ausbreitung einer Offenbarung oder des Christenthums. Wenn werden wir die Bibel in 5 oo Sprachen übersetzt und gedruckt sehen?' [Reimarus], 'Unmöglichkeit einer Offenbarung', p. 325.

10 Zwartjes, 'The Historiography of Missionary Linguistics'; de Souza, 'Political and Linguistic Aspects of the History of Indigenous Linguistics in Brazil'. 
what is interesting for our purposes here is that Reimarus refers to Reland as an authority regarding the languages of America.

A glance at his publications, manuscripts and letters reveals Reland's breadth of interest with regard to the world's languages. The corpus of sources we can rely on is extensive, but also somewhat heterogeneous. In the first place there are a number of succinct dissertations he published in his three-part Dissertationes miscellaneae (1706-1708), from which the contributions devoted to the American languages and the languages spoken on 'some Oriental islands' deserve special mention. ${ }^{11}$ Especially the latter dissertation clearly reveals the extent to which Reland could rely on his voc-informants, many of whom are mentioned in the work. ${ }^{12}$ For the American languages, by contrast, Reland depended on published travel reports. The discovery of America led to an enormous epistemological shock in the Early Modern period. One of the many questions raised by the brand new continent was how its inhabitants had entered this landmass. A number of scholars had tried to find out to what extent the Indian languages could cast light on this vexing issue. Reland in his turn makes an attempt, but closes the work in aporia.

Next, there is his inaugural address on the Persian language. ${ }^{13}$ It concerns a speech delivered in February 1701, that is, at the dawn of the eighteenth century, then just fifty days old. This might explain why Reland deemed it fit to reflect on the past century. Both at the beginning and the end of his speech he bemoans the past golden ages, while deploring the prevailing utilitarian attitude with regard to the study of Oriental languages.

It is hard to put into words how much light the knowledge of these languages casts on sacred literature, as well as on the arts that take their name from humanitas, and how much glory scholars of the highest calibre-so rich was the harvest of such men in the century that lies behind ushave received thanks for these languages. Unfortunately they are no longer among us, great names such as those of Scaliger, Erpenius, Salmasius,

11 For a very recent translation of both dissertations in French, see the well-documented and extensive master thesis by Meyers, Adrien Reland (1676-1718) linguiste et orientaliste. The language-related dissertations in these volumes are the following: De vetere lingua Indica (vol. 1, pp. 209-232); De reliquiis veteris linguae Persicae (vol. 2, pp. 97-266); De Persicis vocabulis Talmudis (vol. 2, pp. 269-334); De linguis insularum quarundam orientalium (vol. 3, pp. 57-139); De linguis Americanis (vol. 3, pp. 143-229).

12 See Reid, 'Indonesian Manuscripts in the Vatican Library'; Pytlowany and Van Hal, 'Merchants, Scholars and Languages'. See also Valentijn, Oud en nieuw Oost-Indiën, p. 86.

13 For a discussion of this work, see Bastiaensen, 'Adrien Reland et la justification des études orientales'. See also Nat, De studie van de oostersche talen, p. 11; de Bruijn, De ontdekking van het Perzisch, pp. 1off. 
Golius, Bochart, Pocock, Selden, Hottinger and many others. Now that envious fate has taken these heroes from us, it seems as though the eagerness to devote oneself to these subjects has waned. In the Low Countries it is not only indifference which has taken hold, but also a harmful aversion to the Eastern letters. For how few scholars actually read the writings of the Arabs and Persians, rather than merely opening them? And how many condemn what they do not understand, and emphasize, as if through divine inspiration, that knowledge of these languages is of no value at all? What is the point, they say, of investing time in the study of these languages? Even if we reach perfect knowledge of these languages we still cannot speak to anyone. What is our connection with Arabs or Persians, people who are so far removed from our world? Those who are considering a trip to these parts of the world will probably be able to benefit from it. But what is the point for those of us who do not intend to cross the borders of our homeland? ${ }^{14}$

These are some of the deceptive arguments, Reland continues, on which opponents are relying in order to discredit our studies.

There is, however, another published contribution by Reland that has hardly been studied so far-his 1715 dissertation on the language of the ancient Egyptians. This text, which cannot be discussed in the frame of this contribution for reasons of space, was included in a volume in the production process of which Reland was initially expected to play a central role. Around 1710 John Chamberlayne (1666-1723) took the initiative of publishing a revised edition of translations of the Lord's Prayer. ${ }^{15}$ In order to persuade Gottfried

14 'Harum cognitione quanta lux oborta sit sacris literis, quanta illis artibus, quae ab humanitate nomen invenerunt, et quam sibi famam paraverint viri summa eruditione conspicui, quorum uberrima fuit seges proximo saeculo, dici vix potest. Fuerunt, proh dolor! illa magna nomina, Scaligeri, Erpenii, Salmasii, Golii, Bocharti, Pocokii, Seldeni, Hottingeri, aliaque plurima. Quos Heroas ubi invida fata nobis eripuerunt, deferbuisse videtur ardor excolendi hoc studium, et invasit Belgium non neglectio tantum, sed turpe fastidium, literarum Orientis. Quam exiguus est eorum numerus, qui Arabum scripta aut Persarum, non dicam, evolvunt, sed legunt? At quantus illorum, qui non intellecta contemnunt, et nullius usus esse harum linguarum cognitionem quasi e tripode pronunciant. Quid prodest, inquiunt, tempus istis linguis discendis locare, quarum licet simus peritissimi, in collocutione cum aliis nulla est utilitas? Quid nobis cum Arabibus aut Persis, populis ab orbe nostro remotissimis? Qui iter in desertas istas regiones instituere cogitat, forte aliquem inde usum percipiet, sed quid hoc ad nos, qui patriae nostrae fines egredi in animo non habemus?', Reland, Oratio pro lingua Persica et cognatis litteris Orientalibus, pp. 6-7; see also pp. 33-34.

On this tradition, see Van Hal, 'Leibniz, das Vaterunser und die Sprachvielfalt'. 
Wilhelm Leibniz (1646-1716) to contribute to this collaborative project, in 1713 Chamberlayne provided an overview of all the prospective assets of the planned volume. Apart from the fact that Chamberlayne claimed he would double the number of language specimens to be included, he also boasted of having improved the method, of having reduced a range of errors, and of having several renowned men on board, all of them willing to write an accompanying essay. Adriaan Reland was mentioned as one of the contributors. Moreover, Reland was also engaged to deal with the typographical aspects of the collection, and might have been supposed to serve as the collection's general editor. ${ }^{16}$ In the end, however, the young scholar David Wilkins (1685-1745) was entrusted with the role of editor, and Chamberlayne also decided to publish the work in Amsterdam instead of Utrecht. The new editor reported in 1714, one year before the volume materialized, that 'Utrecht had no letters for half the languages in which these prayers were written, and had no engraver, but Amsterdam had most of all that'.17 It is also plausible that Reland assisted Johannes Ruëll in publishing his Sinhalese grammar by adding a Roman transliteration..$^{18}$ This shows that in the first quarter of the eighteenth century Reland was seen as an important authority when it came to mapping the world's languages.

As an aside, Reland had already published specimens of the Lord's Prayer. At the end of his third volume of brief dissertations, published in 1708 , he decided to include, in a compact way, thirteen translations of the Lord's Prayer in Slavonic languages, just in order to 'avoid empty pages'.19 Remarkably, Reland invites his readership to compare these Slavonic Lord's Prayers with the Islandic and American vocabulary he offered in his dissertation on the

16 '[J]'ay ajouté un autre Centaine presque; mes Amis me attent que j'ay redressé de Fautes et que ma Methode est plus utile que la derniere, et quelques uns de mes Sçavans Correspondants, comme le Dr Nicolson Eveque de Carlile, le Dr Wotton, Mr le Professeur Reland, ont bien voulu enrichir mon Recueil par des Discours ou Dissertations Epistolaires sur l'origine des Langues, leurs Relations ou Analogie, Changemens etc; le dit Mr Reland a eu la bonté aussi de prendre le soin de faire graver par les meilleurs Mains plusieurs des versions dans les Langes orientales et de faire imprimer toutes les restes à Utrecht'. Cited after Zulaika Hernández, 'Nuevos datos sobre las obras vascas de Pierre d'Urte', p. 325.

17 Anon., The Manuscripts of the Duke of Portland, p. 456.

18 Reland, 'Dissertatio de linguis insularum quarundam orientalium', pp. 81-82. Pytlowany and Van Hal, 'Merchants, Scholars and Languages'.

19 'Ne pagellae quaedam vacent'. Reland, Dissertationum miscellanearum pars tertia, unnumbered page (fol. S 3 ). The data was drawn from a table that was inserted in Johann Weikhard von Valvasor's (1641-1693) chorographical work on the Duchy of Carniola, which is today the central part of Slovenia. See von Valvasor, Deß Hochlöbichen Hertzogthums Crain, table inserted between pp. 274-275. 
American languages. One can imagine how baffled his readership must have been, particularly since the material offered in that dissertation had hardly any overlap with the vocabulary included in the Lord's Prayer.

Since not all published works by Reland have been studied in depth, it comes as no surprise that this applies even more to his manuscript legacy. 'Manuscript legacy' should be understood in a double sense. On the one hand, there is the rich collection of manuscripts he accumulated during his life, some of which he enriched with his own annotations. In a 'Dictionary of Sanskrit or of the language of the Brahmans', now preserved in the Vatican library, Reland expresses, for example, his astonishment about the more than forty synonyms for 'sun' and more than twenty for 'moon.' ${ }^{20}$ In one of the letters Reland exchanged with Mathurin Veyssière de la Croze (1661-1739) via Gisbert Cuper (1644-1716), who served as a hub of epistolary exchange, he explained that he had shared all his Chinese manuscripts, stemming from Martino Martini's (1614-1661) and J. Golius's (1596-1667) legacy, with a certain mister 'Masson', a French scholar who was staying in the Netherlands as a private teacher. ${ }^{21}$ This suggests how Reland wanted to make his manuscript treasures productive in the Respublica litterarum.

At the same time we have a number of manuscript letters written by Reland which cast some light on his interest in remote languages. Two important correspondents of Reland were Gisbert Cuper, an all-round classical scholar with a special interest in coins and medals, and Nicolaes Witsen (1641-1717), the mayor of Amsterdam and one of the chairmen of the voc. In a letter to Witsen, Reland writes:

I have often been told that you, Sir, own many Indian manuscripts, among which several in unknown characters. I am very curious to know more about these, since I myself own some Javanese, Malayan, Japanese, Chinese and other manuscripts, and cannot think what these unknown

20 Vatican City: Bibliotheca Apostolica, ms Vat. Ind. 8. 'Sjasjanam est liber, Nama est nomen, Lingam genus. Nam in hoc libro distinguuntur singulae voces per genera sua' (f. 140); for the names of the sun, see ff. $5^{6-57}$, and for the moon, see ff. $5^{\circ-51}$.

21 'Ego in Sinicis versatum hominem in patria nostra nullum novi praeter Gallum quendam, Masson nomine, qui in pago non longe hinc, Capelle dicto, aliquot annos exegit, praepositus studiis Nobilis juvenis Belgae, qui illic habitat. Communicavi cum eo, omnia mea Sinica m[anu]s[crip]ta, quae a Martino Martinii et Golio profecta sunt, et saepe illum hortatus sum, ut specimen aliquod Sinicum ederet; quod promisit, sed ultra promissa nihil hactenus ab eo extorquere potui', Cuper, Lettres de critique, p. 108. See also the contribution of Anna Pytlowany in this volume, p. 278. 
characters might be: although it is said that in some islands to the east of Java, writing is used that is still unknown to us. ${ }^{22}$

In a subsequent letter (dated 1714), he further explains:

I have often heard that apart from Malay, Singhalese, Javanese, Siamese, Chinese, Japanese and some other languages about which enough information is available, there are other scripts used on some oriental islands, which are entirely different from the others. From Borneo we have nothing apart from the Malay and Portuguese that is spoken on the shores, but who knows what kind of script is used in the heart of the island's interior? ${ }^{23}$

It is interesting to note that Reland was very well aware that there were still many languages to be discovered, in the East as well as in the West: in his dissertation on the American languages he explained that 'there were many languages the existence of which had not yet reached the Europeans. ${ }^{24}$

This very brief survey has made clear that Reland seems to have been interested in all languages that were spoken, and especially written, on earth.

\section{Comparing the World's Languages: Why and How?}

The above prompts us to ask the pressing question: why was Reland interested in these exotic languages? We have seen that Reland was a passionate advocate of the Oriental tongues, including languages such as Hebrew, Arabic and Persian (the last of which, we now know, belongs to the Indo-European

22 Cited in Peters, 'From the Study of Nicolaes Witsen (1641-1717)', p. 32. 'Mij is dikwils gesegt dat $\mathrm{U}$ Wel[edele] veele Indiaanse manuscripten besit, en daer onder eenige met onbekende characters. Ik ben seer nieusgirig te weten wat daer van zij. dewijl ik seleve ook al eenige Javaanse, Maleysse, Japanse, Sineese en andere manuscripten besit, en niet kan nadenken wat voor onbekende charcters dat zijn: hoewel men seydt dat er op sommige eylanden ten oosten van Java nogh schrift gebruykt werd dat ons onbekend is'.

23 'Ik heb dikwils gehoort dat buyten het Maleys, Singalees, Javaans, Siaams, Sinees, Japonnees en eenighe andere taalen, daer men genoeg faam naright van heeft nogh schrift is op sommighe oosterse eylanden, dat gansch ver schillende is van de andere. Van Borneo heeft men niets, als dat men op de zeekusten Maleys spreekt of Portugees, dogh wat voor schrift binnens lands gebruykt word, wie weet dat?' (unpublished manuscript, University Library Amsterdam).

24 'Plurimae enim sunt, quarum notitia ad populos Europaeos nondum pervenit', Reland, 'Dissertatio de linguis insularum quarundam orientalium', p. 103. 
language family). His interest in such languages could be easily motivated by highlighting their relevance for Biblical studies. But this does not hold true for languages such as Malay and Nahuatl. Later, in his oration on the dignitas and praestantia of Persian, Reland also stresses the significance of Persian for enhancing knowledge about history. 'In addition', Reland states, 'our [classical] authors tell many dubious and ridiculous stories about Zoroaster, the teachings and rites of the ancient magicians, and the rituals of Mithras, which first spread from the Persians to the Egyptians'. Here we see how the initially almost blind adoration for classical historiographers, which was prevalent until well into the seventeenth century, has given way to a significantly more critical approach to ancient writings. 'Without knowledge of the Persian language', Reland adds, 'we can only admit that we ourselves are in the dark to such an extent that even the name of Zoroaster has until now not been correctly written or pronounced among Europeans.25

In one of his dissertations, Reland gives some very enlightening background to his aims:

It is by no means my aim to offer here full grammars or vocabularies of the languages to be discussed. I just want to give the readers a specimen of the letters used by those peoples in writing [...] or of some rather daily words, from which one can evaluate the resemblance of these languages to others, and the origins of the peoples themselves—origins are very often to be detected by examining linguistic kinship. ${ }^{26}$

This is, in many respects, a very revealing statement. First of all, Reland emphasizes that he does not envisage offering complete linguistic tools. Needless to say, such an endeavor would cross the boundaries of feasibility. But even if it had been feasible, Reland seems to suggest that this would not matter so much. His principal goal consists in giving his readership an idea of what a certain language looked like. This reminds us of John Smith's addition of

25 'Adde, quod incerta plurima et ridicula narrentur ab auctoribus nostris de Zoroastre, de veterum Magorum disciplina et ritibus, de sacris Mithriacis, quae a Persis primum ad Aegyptios propagata sunt, in quibus, sine cognitione linguae Persicae, caecutire nos adeo fatendum est, ut ne nomen quidem Zoroastris, recte inter Europaeos scriptum fuerit hactenus, aut pronunciatum'. Ibid., pp. 20-21.

26 'Nequaquam vero propositum mihi est illarum linguarum, de quibus agam, Grammaticas integras aut Lexica hoc loco exhibere, sed tantum lectori aliquod specimen dare tum literarum quibus istae gentes in scribendo utuntur, [...] tum communiorum vocum, ex quibus judicium ferri potest de convenientia harum linguarum cum reliquis, et ipsorum populorum originibus, quae ex sermonis affinitate cum aliis saepissime deteguntur'. Ibid., p. 78. 
a Virginia Algonquian vocabulary to his map of Virginia, subheaded with the text 'Because many doe desire to knowe the manner of their Language, I have inserted these few words. ${ }^{27}$ Laura J. Murray was right in stressing the significance of the word manner: 'people want to hear it, not speak it, Smith perceived'. ${ }^{28}$ So does Reland suggest here that the range of linguistic specimens he is offering only serves to satisfy his audience's curiosity? ${ }^{29}$ In a way he does. But the word 'curiosity' needs qualification here: it does not concern 'non-committal curiosity', given that Reland seems to assume that his readers' curiosity is motivated by their interest in the similarities between different languages. Such linguistic kinship, in turn, allows one to trace the prehistory of mankind. This is an idea that was also extremely prominent in Leibniz's contemporary writings. ${ }^{30}$ Both scholars thus seem to have strongly believed in the basic assumption that languages could help shed light on the prehistory of mankind. In this regard it is astonishing to find that Leibniz and Reland never seem to have been directly in touch with each other, although both men had developed an impressive espitolary exchange. The number of Reland's letters that have been preserved is, in comparison to Leibniz's correspondence, much more modest, and deserves to be investigated as a project in its own right.

The enormous scope of Reland's topics-the languages he describes and/ or compares cover the entire world-could give rise to the suspicion that the Utrecht scholar would at times go too far in his adventurous audacity. However, nothing could be further from the truth. Reland was very well aware that whoever attempted to compare remote languages risked treading on dangerous ground. He deplored that many all too enthusiastic colleagues had not adopted a sufficiently cautious approach, and that a flood of senseless etymologies had meanwhile contaminated the vulnerable field, thus strengthening scholars who had no belief whatsoever in the value of etymology. He himself explicitly contrasted the inherently conjectural nature of etymology with the watertight principles mathematics was built on, and preferred observing silence to formulating bold etymologies. ${ }^{31}$

27 Smith, The Generall Historie of Virginia, p. 40.

28 Murray, 'Vocabularies of Native American Languages', p. 594.

29 A recent book on the role of curiosity in Early Modern linguistic research is Considine, Small Dictionaries and Curiosity.

30 See several contributions in Li, Einheit der Vernunft und Vielfalt der Sprachen; Carhart, Leibniz Discovers Asia.

31 Reland, 'Dissertatio de linguis Americanis', pp. 152-153; Reland, 'De reliquiis veteris linguae Persicae', pp. 98, 181-182. Cf. Bastiaensen, 'Adrien Reland à la recherche d'une méthode comparative', pp. 52-53; Van Hal, 'Moedertalen en taalmoeders', p. 448. 
Reland shows another example of his analytical mindset when discussing the possible causes of language similarity. Such typologies are indeed rather rare in Early Modern treatises. ${ }^{32}$ 'If one wants to claim that one language stems from another', Reland argues, 'it is not enough for there to be some words which show resemblance.' ${ }^{33}$ Similarity between just a few words can be based on mere chance or on the principle known today as iconicity. Words referring to animals or auditive phenomena tend to have similar forms in many languages in that they imitate similar sounds. However, this is not tantamount to saying that these languages are related. ${ }^{34}$ Today the cuckoo is often used as an example of this principle, but Reland illustrates it by listing a range of other words, the first of which is 'to gargle', which he refers to in Dutch (gorgelen), Latin (gargarizare) and Arabic (غرغر). In addition, Reland continues, not all words qualify for comparison: in order to demonstrate genealogical kinship one's research should be based on common and simple words, such as numbers. ${ }^{35} \mathrm{It}$ is important to note that the Latin word communis, just like the English word common, is somewhat ambiguous-especially in this context, as it can mean 'general', 'familiar', 'ordinary' (cf. English 'it is a very common error'), as well as 'shared' (cf. English 'we have much in common'). Reland makes use of both meanings throughout his dissertations, but he tends to employ the comparative communior when referring to the former meaning. In so doing Reland shows how he particularly emphasized the relevance of comparing words that belonged to the so-called 'basic vocabulary'. A recent textbook on historical linguistics describes the notion of 'basic vocabulary' as follows:

Most scholars insist that basic vocabulary should be part of the supporting evidence presented in favour of any distant family relationship. Basic vocabulary is usually not defined rigorously but is understood generally

32 See for other examples Van Hal, 'Moedertalen en taalmoeders', p. 441.

33 'Nec enim sufficit, ut una lingua ex alia orta dicatur, voces quasdam inter se convenire'. Reland, 'Dissertatio de linguis Americanis', p. 146.

34 'Praeter casum fortuitum, cui saepe convenientia duarum vocum in linguis diversissimis debetur, possunt nonnunquam et aliis de causis voces convenire, licet una ab alia ortum non acceperit, si ita formatae sint, ut sono suo rem quam significant, exprimant, quod manifestissimum est in iis vocabulis quae ad exprimendos sonos tum animalium tum rerum in animatarum, uti venti, tonitru, aquarum, ponderum delabentium, collisorum, trementium facta, \&c. sunt'. Ibid., p. 148.

35 'Praeterea ortus unius linguae ex alia non ex vocibus rarioris usus aestimari debet, (quod saepe fit ab iis qui convenientias vocum indagant) sed communioribus, uti numeris, quorum notae in omnibus linguis inveniuntur; et ex simplicissimis, non iis quae ex duabus, tribusve, aliis vocibus compositae sunt, quales in Asiaticis linguis, atque Americanis inveniuntur plurimae'. Ibid., pp. 150-151. 
to include terms for body parts, close kinship, frequently encountered aspects of the natural world (mountain, river, cloud and the like) and low numbers. Basic vocabulary is in general resistant to borrowing, and so, similarities found in comparisons involving basic vocabulary items are unlikely to be due to diffusion and hence stand a better chance of being evidence of distant genetic relationships, of being inherited from a common ancestor, than other kinds of vocabulary. ${ }^{36}$

Elsewhere, Reland gave some more examples of what he understood by 'common nouns', apart from numbers. ${ }^{37}$ Especially insightful is a catalogue of 67 basic words which served as a starting point for comparing Chinese, Japanese and Vietnamese, ${ }^{38}$ followed by an overview of the numbers from 1 to 1000. I here list the English translations of the Latin entries of Reland's comparative table.

1) Heaven; 2) Earth; 3) Real; 4) Lord; 5) Person; 6) Man; 7) Woman; 8) Wife; 9) Husband; 10) Father; 11) Mother; 12) Brother; 13) Sister; 14) Son; 15) Daughter; 16) Grandfather; 17) Grandmother; 18) Boy, girl; 19) Heaven, sky; 20) Fire; 21) Air; 22) Water; 23) Earth; 24) Sun; 25) Moon; 26) Star; 27) Mountain; 28) River; 29) Year; 30) Month; 31) Day; 32) Night; 33) Slave; 34) City; 35) Sword; 36) Bread; 37) Wine; 38) Good; 39) Bad; 40) Death (to die); 41) Sack; 42) Eat; 43) Drink; 44) Talk; 45) Black; 46) White; 47) Yellow; 48) Red; 49) Green; 50) Blue; 51) King; 52) Lightning ( fulmen); 53) Thunder; 54) Lightning (coruscatio); 55) Cloud; 56) Head; 57) Arm; 58) Hand; 59) Feet; 6o) Legs; 61) Hair; 62) Mouth; 63) Nose; 64) Ears; 65) Teeth; 66) Beard;67) Forehead.

It is very revealing to see how much overlap there is between Reland' intuitive list of basic items and the items that are currently seen as 'basic vocabulary'. The entries in bold also surface in the well-known list of 100 basic words established by Morris Swadesh (1909-1967) in the mid-twentieth century, which was designed to enable large-scale lexical comparison. The items in italics can be found in an originally more extensive list by Swadesh, containing 200 items. ${ }^{39}$ Importantly, however, we should note that Swadesh too

36 Campbell, Historical Linguistics, pp. 348-349.

37 Reland, 'Dissertatio de linguis Americanis', p. 145.

38 'Sed ecce tandem ipsum Catalogum vocum communiorum ...' Reland, 'Dissertatio de linguis insularum quarundam orientalium', p. 112.

39 https://concepticon.clld.org/contributions/Swadesh-1964-10o; https://concepticon.clld .org/contributions/Swadesh-1952-20o. 
seems to have created his lists intuitively. Besides, the reliability of his lists has been disputed by more recent linguists who have shown that not all the basic words identified by Swadesh are so basic that they can withstand borrowing. ${ }^{40}$ Finally, it should be noted that Reland was far from being the first scholar to underline the methodological importance of basic vocabulary, ${ }^{41}$ although it is fair to say that Reland implemented the idea in a very tangible way.

Thus relying on such lexical principles Reland was exceptionally successful in detecting and establishing the kinship between Malagasy, a language of Madagascar, and Malay, the lingua franca in Indonesia. These languages are currently known to belong to the Austronesian language group. Reland was able to connect these languages by comparing a number of manuscript vocabularies he obtained thanks to his voc contacts. Despite being based on lexical comparison alone, this was a major achievement for that time-one which is still well-known today as it is mentioned in a host of recent textbooks and research papers. ${ }^{42}$

In the Early Modern period many humanists were eager to match different languages with similar names, such as Goths and Getes, or Armenians and Aramaeans. Reland was one of the few humanists who objected to reading so much into a mere similarity between two ethnonyms. With regard to languages spoken in Asia, Malay (Indonesian) and Malabaric (Tamil or Malayalam) were often erroneously identified.

What we have said about the Malabaric language shows sufficiently that it is not identical to Malay [...]. Neither the characters nor the words and their meanings are similar, nor are the languages used in the same places. There is nothing that can make anyone believe that Malabaric and Malay are one and the same, apart from a shadow of similarity in the names of both languages. ${ }^{43}$

40 Tadmor, 'Loanwords in the World's Languages: Findings and Results', pp. 72-73.

41 Van Hal, 'Moedertalen en taalmoeders', passim.

42 See e.g. Melebek, Sejarah bahasa Melayu, p. 2; Pawley, 'Explaining the Aberrant Austronesian Languages', p. 221; Donohue and Denham, 'Farming and Language in Island Southeast Asia', p. 227.

43 'Haec quae de lingua Malabarica notavimus satis ostendunt non esse illam eandem cum lingua Malaïca [...]. Nec characteres literarum, nec voces, earumve significationes conveniunt, nec iisdem in locis hujus et illius usus est, nec quicquam est, quod aliquem persuadere posset linguas Malabaricam et Malaïcam esse unam eandemque, nisi convenientia aliqua quae inter nomen Malabaricum et Malaïcum est'. Reland, 'Dissertatio de linguis insularum quarundam orientalium, p. 91. 
It may be that such linguistic and methodological insights help explain why Reland gained such a strong foothold among later linguists. ${ }^{44}$ It is indeed safe to say that Reland's writings on languages other than the Semitic ones were well-received throughout the entire eighteenth century, and that some of them even 'survived' the nineteenth century. In his 1762 Course of lectures on the theory of language, and universal grammar, a very wide-ranging overview of all matters linguistic, the British polymath Joseph Priestley (1733-1804) included Reland's dissertations in his succinct 'further reading section', as one of the very few non-English references. ${ }^{45}$ We have already seen that his astute observations on the Austronesian language group are still relatively well-known today, which is probably the result of the continuous attention that was given to Reland's dissertation. When the versatile British scholar William Marsden (1754-1836) elaborated on Reland's observation that Malay and Malagasy were related, ${ }^{46}$ there is no doubt that Marsden must have been familiar with Reland's work, since Marsden published, in two editions, a catalogue of his impressive book and manuscript collection with a clear focus on Oriental philology and linguistics. He did not fail to mention Reland's dissertationes. ${ }^{47}$ Reland's success in revealing the kinship between the Austronesian languages led Georg von der Gabelentz (1840-1893), a German Sinologist and general linguist in the Humboldtian tradition, to declare him in 1891 to be 'the first comparative linguist - in the present-day sense of the word - known to me. ${ }^{48}$ The last section of this contribution demonstrates why Gabelentz' assessment was probably all too benevolent.

\section{A Discussion between Reland and William Wotton on the Origins of Present-Day Language Diversity}

That Reland has not been successful in all regards was also pointed out by a number of later scholars. The Roman Catholic cardinal Nicholas Wiseman (1802-1865), for instance, summarized the nineteenth-century criticism of Reland's approach in his dissertation on the Indian language as follows:

44 For some other of Reland's comparative merits, see Bastiaensen, 'Adrien Reland à la recherche d'une méthode comparative', pp. $5^{1-52}$.

45 Priestley, On the Theory of Language, and Universal Grammar, p. 305.

46 Carroll, 'William Marsden and Patterns of British Scholarship in the Malay Peninsula', p. 270.

47 Marsden, A Catalogue of Dictionaries, Vocabularies, Grammars, and Alphabets, p. 56.

48 von der Gabelentz, Die Sprachwissenschaft, p. 27. 
He had collected the Indian words preserved in ancient authors, and found that many of them could be illustrated from the Persian. Yet this did not lead him to suspect an affinity between the Indian and the Persian languages. But as he knew no grounds on which to resort to the usual expedient of supposing that one had given birth to the other, he was unable, upon any principle then known, to solve this problem; and therefore concluded that the words so collected were not Indian but Persian, and that the ancients had been mistaken in giving them as Indian. ${ }^{49}$

Similar criticisms had been voiced in the course of the eighteenth century. ${ }^{50}$ 'The Utrecht scholar was not, by any means, a genius ahead of his time', Michel Bastiaensen rightly notes. ${ }^{51}$ It is indeed safe to say that Reland in many respects remained a child of his time. His interest in the prehistory and cradle of mankind did not imply that he was no longer reliant on the Biblical framework. On the contrary, his interest in the languages of the Oriental islands was partly motivated by his endeavors to localize 'Ophir', the extremely wealthy Biblical region from which King Solomon imported cargoes of gold and silver. He also expressed the idea that all languages had their roots in Hebrew, with the exception of some 'artificial languages' including Japanese and Chinese. ${ }^{52}$ Nevertheless, Reland's belief in Hebrew as the primeval language has, albeit mildly, been called into question. Bastiaensen correctly observes how 'Reland paradoxically succeeds in affirming the Hebrew origin of languages, while accumulating facts that only weaken this position: one can therefore wonder whether he really believed in the primacy of Hebrew and whether this was not rather a way of adhering to convenience and being cautious. ${ }^{53}$

49 Wiseman, 'The Comparative Study of Languages (Part 1)', p. 12.

5o 'If Reland be well founded in his opinion, that many of the words mentioned by ancient authors as Indian are really Persian, we may conclude that there was an early intercourse between Persia and India, of which hardly any trace remains in history'. Robertson, $A n$ Historical Disquisition Concerning the Knowledge Which the Ancients Had of India, p. 338.

$5^{1}$ Bastiaensen, 'Adrien Reland à la recherche d'une méthode comparative', p. 53.

$5^{2}$ 'Hae enim de novo confictae sunt artificiose a sapientibus illorum populorum, qui ut omnem doctrinam intra societatem suam continerent, et viam ad scientias difficiliorem redderent, veteri linguae abolitae novam, eamque monosyllabicam, ac certis modulis sonisque adstrictam, et aliquot vocum millibus intricatam substituerunt (quod de Sinensi omnino affirmandum videtur) vel ab origine sua Hebraea ita abeunt, ut convenientia, quae inter illas intercedit, agnosci nequeat. Saltem hactenus a quoquam cum successu tentata non sit, quod sciam, illorum sermonum derivatio ex fontibus Hebraeis'. Reland, 'Dissertatio de linguis Americanis', pp. 144.

53 'Au demeurant, dans sa préface, Reland réalise le paradoxe d'affirmer l'origine hébraïque des langues, tout en accumulant des faits qui ne font qu'affaiblir cette position: on peut dès lors se demander s'il y croyait vraiment et s'il ne s'agissait pas plutôt d'une formule 
In order to find out what ideas Reland developed about the primeval language and the factors underlying present-day linguistic diversity, we need to collect his statements on this subject as pieces of a puzzle. In his book on the languages of the Amerindians, he states:

But if someone would ask my opinion on the similarities between the American languages and the languages of our continent, given that it is crystal-clear that the American peoples can be traced back to Noah: just like our forebears, their forebears must have employed a certain language, or languages, which do not differ to such an extent from Hebrew as the languages which are currently in use. However, in my opinion, the languages that are nowadays spoken among the Americans do not reveal any hint of their Hebrew roots [...]. I therefore think that the languages of the Americans have so far been compared in vain to Hebrew. ${ }^{54}$

This remains a little puzzling: does Reland seek to trace the languages of the Indians back to Hebrew or not? It might be helpful to bring this idea into connection with a statement he made in a letter to Gisbert Cuper, which no longer survives as such, or which, at least, is currently unlocated. Parts of this letter, however, are still known, because Cuper cites from it in a letter to Otto Sperlingius (1634-1715). The extensive literary exchange between both scholars was published in 1737. In this indirect way we learn how Reland 'completely disagrees with scholars who opine that the builders of the Tower at Babylon returned to a single tongue as soon as they ceased their work'. And Reland continues: 'Nor am I convinced that the various languages of the world as they are known to us today originated at that place. ${ }^{55}$ At first sight this statement seems to indicate that Reland rejects the biblical story, thus undermining the position

de commodité et de prudence'. Bastiaensen, 'Adrien Reland et la justification des études orientales', p. 21.

54 'Quod si aliquis a me quaerat, quid ego sentiam de convenientia harum linguarum cum linguis nostrae continentis, quum sine dubio gentes Americanae eundem nobiscum Noachum parentem habeant, et ex aliquo trium filiorum ejus natae sint, ipsorum quoque proavi, uti et nostri, lingua aliqua, vel linguis, usi olim fuerunt, quae non adeo ab Hebraea discrepabant, ac illae quibus nunc utuntur. Has vero quae hodie in usu sunt apud Americanos ego existimo nulla praeferre ortus sui ex lingua Hebraea indicia [...] sic ut meo judicio frustra hactenus ad hunc finem comparatae fuerint Linguae Americanae cum Hebraea'. Reland, 'Dissertatio de linguis Americanis', p. 146.

55 'Plane non sentio cum iis, qui rediisse ad linguam unam architectos turris Babylonicae autumant, postquam ab opere illo cessarunt; et ego nequaquam mihi persuadeo, diversas linguas ibi ortas fuisse, quas nunc per orbem terrarum esse usitatas novimus'. Polenus, 'Gisberti Cuperi et Ottonis Sperlingii dissertationes', p. 278. 
of Hebrew as the first language. But thanks to a dissertation by William Wotton (1666-1727) which is well worth reading, we realize that this is by no means the case. We should therefore dwell briefly on Wotton's publication, which has so far only attracted limited scholarly attention.

Just like Leibniz and Reland, Wotton had contributed to Chamberlayne's Lord's Prayer project by submitting an essay as a letter to Chamberlayne in 1713. ${ }^{56}$ Posthumously, however, an edition of the original English letter was being sold for one shilling, as can be inferred from the title page of A Discourse Concerning the Confusion of Languages at Babel. In the opinion of the anonymous editor, such a publication was not superfluous, given that the discourse as printed in Chamberlayne's collection was 'with great Disadvantage both to the Author and the Reader'. 'The frequent Mistakes committed [in] it', the editor continues, 'were so obvious, that they could not escape without Censure. And I thought it but Justice due to Dr. Wotton's Memory, to give an Edition as it came from his own Hand'. ${ }^{7}$ What the editor fails to mention here, is the fact that the letter in Chamberlayne's volume was translated into Latin. Wotton applauded Chamberlayne's plan:

Your Collection of Lord's Prayers in so many different Languages, some dead, some living, some ancient, some modern, which so few Scholars, comparatively speaking, would judge to be worth the Pains, and Study and Expense that you have been at to collect, led me to think that the famous Problem concerning the Confusion of Languages that happened among the Workmen of the Tower of Babel, might by comparing many Languages together, be determined even to a Demonstration; and that by knowing the Succession of those Tongues, with which we are in some tolerable Measure acquainted, and comparing their several Characteristicks by which they are essentially and formally distinguished from one another, we may come to know, whether God did then miraculously create new Tongues, and so consequently force those Workmen to separate for want of understanding what each other said, or whether he only made them quarrel, and thereby induced them to part, and so leave their Work unfinished. ${ }^{58}$

After announcing that he will support the first position, which is 'most agreeable to the Text', Wotton dives into Biblical hermeneutics by discussing the

$5^{6}$ Wottonius, 'Dissertatio de confusione linguarum Babylonica'.

57 Wotton, A Discourse Concerning the Confusion of Languages at Babel, p. 70.

$5^{8}$ Ibid., pp. 6-7. 
crucial passages in Genesis. He defends the thesis that the Hebrew word shaphah can indeed refer to 'language'. It is very fascinating to observe how he then summarises, in very clear language, another argument of his opponents, arguing against a miraculous genesis. 'We see in a thousand Years', so he introduces the new point, "what Alterations and Deviations have been made from the Latin in France, Italy, Spain, and the Subalpine Regions.' ${ }^{59}$ Many examples follow, emphasizing the mutual unintelligibility of several closely related Germanic and Romance languages. 'The IsIandish (or the old Norn, or Norwegian Language) which is the Mother of the Danish and Swedish Idioms, is not intelligible now without Study, by a Native of Copenhagen or Stockholm.60 This brings him to the following conclusion, aired by his opponents.

If then, say those who think that this Confusion was not miraculous, such Alterations are actually visible in Dialects which have been formed from Languages still extant, in so few Years, what may we reasonably suppose to have been in Languages that existed above three Thousand Years ago?

The question is significant, because we see here how empirical findings led to reinterpretations of the biblical story before they would eventually usher in the end of its literal readings. Although not undermining the validity of the above question, Wotton puts forward an interesting counter-argument, which is twofold in nature. First, the examples given show how all these languages are 'manifest Deviations from one common Original, tho' not all from the same'.61 Some of the languages can be traced to Latin, but other languages must stem from other originals: 'there are several such common Originals in the World'. And second, these languages, although they 'may have some few Words in common', are characterized by 'a quite distinct Frame and Make from many others; and this Frame and Make runs thro', and is manifestly visible in their Subdivisions, and has been so from all Antiquity'.62 I will return to this argument, which Wotton develops in the following ten pages or so, in more detail later on. Taking into account that 'by the lowest Computation the Earth was M DCCXVII Years old, when this Confusion happened; and that by that Account it is not six Thousand Years old now',63 he therefore reaches the conclusion that, 'considering the Time that has elapsed since the Building of the Tower of

$\begin{array}{ll}59 & \text { Ibid., p. 12. } \\ 60 & \text { Ibid., p. 13. } \\ 61 & \text { Ibid., p. 14. } \\ 62 & \text { Ibid., p. 15. } \\ 63 & \text { Ibid., p. 31. }\end{array}$ 
Babel; and considering what Progress and Alterations some of the Languages which we know have made in three Thousand Years $[\ldots]^{\prime},{ }^{64}$ the fundamental diversity of languages can only be accounted for by invoking a miraculous design of languages.

The above statement is of special interest, because Wotton formulates an explicit assumption here which is, in a merely implicit way, truly seminal and all-pervading in the Early Modern mindset, while at the same time being very far removed from our present-day thinking. The reasoning of my opponents, Wotton thus suggests, is valid if-and only if-our earth is much older than it really is - in other words, it should be much older than fifty centuries or so. Indeed, Wotton's train of thought thus makes clear the extent to which contemporary views on our planet's life-span impacted ideas on prehistory. If we as 21st-century readers try to interiorise such an extremely restricted life-span, it suddenly becomes much less absurd to speculate, for instance, about the nature of the original 'primal language'. And it also explains why there had been, in Wotton's view, simply not enough time for a gradual coming into being of such a fundamentally diversified linguistic landscape. 'Let any Man look here in Europe into the Finnish Tongue, and its Dialects, the Esthish, and the Lettish; let him examine the Hungarian, which is a Language entirely different from any other spoken in Europe. ${ }^{65}$ Further on he mentions, among other languages, Gaulish, Persian and Chinese as plausible original languages. ${ }^{66}$

Wotton concludes his dissertation by mentioning that he had received 'some Objections which our excellent Friend Mr. Reland did me the Honour to send me, when I sent him a Sketch of my Thoughts some Years ago, upon this Subject'.67 This thus implies an epistolary exchange between Wotton and Reland predating 1710 or so. Wotton is so kind as to take his time in formulating Reland's opinion on this matter:

His Notion is much the same with Stiernhielmius's, that there were no Tongues formed in Babel; but that either they have all been derived by gradual and imperceptible Alterations from the Hebrew, which he takes for granted was the Language of Noah, or were formed at once by mutual Agreement. And that if we consider what an entire Separation of all Intercourse; a Disability in some Nations of pronouncing four or five Letters, which are Familiar to other People, by Reason of the different

\footnotetext{
64 Ibid., p. 36 .

65 Ibid.

66 Ibid., pp. 42-43.

67 Ibid., p. 55 .
} 
Disposition of the Organs of their Speech; what different Customs and different Diet will produce, this is not so much to be wondered at. ${ }^{68}$

Indeed, we see how Reland, in his dissertations, traces some Greek, Latin and Dutch words back to Hebrew (such as vinum, wyn, oivos ['wine'] to "י"). ${ }^{69}$ This was common practice in the Early Modern period, and in combination with Wotton's testimony, we can be quite sure that Reland truly believed Hebrew to be the primeval language, thus doing more than paying just lip service. Wotton then paraphrases Reland's objections (which are four in number) and his own answers to these criticisms, three of which I will succinctly present here.

If one assumes that God suddenly created new languages 'in order to oblige the Workmen to disperse', Reland asks, why do we see that 'those Colonies which spoke Languages that were nearly akin to one another' remained neighbours? We would expect, rather, that tribes with similar languages would be 'removed at the greatest Distances and those whose Languages were entirely different placed next one another. The Chineses for the Purpose should have been planted near the Chaldeans and their nearest Neighbours removed into China. This would have done the Work to Purpose [...]'. Wotton is forced to acknowledge that Reland's reasoning is ingenious and valid, and he does not offer a really convincing rebuttal.

In another objection, we learn more about Reland's ideas about Japanese and Chinese as being artificial languages.

But Mr. Reland supposes that some Languages have been made by Agreement all at once. Thus he thinks that the Chinese, and the Language of the Incas of Peru were at first imposed upon those People at the Command of the Sovereigns of those Countries who might imagine and not improbably by this Means to keep their Subjects together and to hinder them from mixing with other Nations. ${ }^{70}$

Reland's strong belief in Hebrew as the world's first language and his conviction that languages had developed only gradually from Hebrew may have prompted him to embrace this rather idiosyncratic idea. Wotton counters Reland by pointing out that such an imposition could be only successful in a 'Monarchy where the Sovereign is entirely absolute and where the People are disposed to pay a religious as well as an entire Obedience to all his Commands.

68 Ibid., pp. 42-43.

69 Reland, 'Dissertatio de linguis Americanis', p. 151.

70 Wotton, Discourse, pp. 65-66. 
That was the Case of the Chineses and Peruvians and more so perhaps than of any other People in the World: ${ }^{71}$ Both Wotton and Reland do not seem to wonder how a monarch can suddenly make an entire population speak another language, but their silence in this regard could possibly be explained by taking into account the typically Early Modern assumption that a specific language is strongly linked to a specific script — and it seems to be more obvious to impose a written script than a spoken language. ${ }^{72}$ Indeed, we have already seen that Reland tends to make a connection between language and script, and that he is first and foremost interested in the latter, especially when one reads his dissertation on the eastern islands. Whatever it may be, Wotton goes on to argue that many other peoples have never been troubled by such a strict monarchy, probably ignoring the fact that Reland only invokes the authoritarian imposition of an entirely new language for explaining why certain languages can in no way be linked to Hebrew. Reland would probably have answered that the counterexamples given by Wotton, peoples without continuous tradition of living in an absolute monarchy such as the Germans, did not undermine his point, in that German could be ultimately traced to Hebrew.

Wotton, however, makes a very important point when addressing the first criticism voiced by Reland. The European tongues, Reland argued, have so much affinity with the Hebrew language that one should assume that they could be traced back to that language and that they have not been designed suddenly. ${ }^{73}$ Wotton's reply to that criticism is of the utmost significance:

My Argument does not depend upon the Difference of Words, but upon the Difference of Grammar between any two Languages; from whence it proceeds, that when any Words are derived from one Language into another, the derived Words are there turned and changed according to the particular Genius of the Language into which they are transplanted. ${ }^{74}$

Wotton thereupon argues that the points of community between Icelandic and Greek can be explained by invoking 'one common Mother which is and perhaps has for many Ages been entirely lost. ${ }^{75}$ On the other hand, he demontrates that " $\mathrm{n}]$ ot one European Language that is derived from a Greek or Teutonic Stock declines its Verbs any otherwise than according to an active

\footnotetext{
71 Ibid., p. 66.

72 For a recent example of top-down language planning, see Lewis, The Turkish Language Reform: A Catastrophic Success. I owe this reference to one of the anonymous reviewers.

73 Wotton, Discourse, p. 56.

74 Ibid., p. 57.

75 Ibid.
} 
or a passive Form. Not one of them affixes possessive Pronouns to the Nouns, to which they belong: ${ }^{76}$ A short list of similar characteristics follows.

In every of these Particulars we find an essential Difference in these Languages from those Eastern ones, which are related to the Hebrew. And there is no doubt but many other grammatical Observations may be made, by which the different Construction of these European and those Asiatic Languages would appear yet more plainly, if these should not be thought sufficient. ${ }^{77}$

Wotton's conclusion is in our present-day eyes a model of iron logic: the lack of grammatical similarities implies that any similarities between Hebrew and the European languages should be explained in terms of borrowings:

I do not therefore think that the Affinity between many European Tongues and the Hebrew, upon which our Friend lays so great a stress, even though it were much greater than it is, proves what he designs it should. It may be very easily accounted for by those that know that the Phenicians carry'd on all the Trade of the Mediterranean for many Ages. ${ }^{78}$

Many readers will recall how it was precisely the attention given to similar grammatical structures that had given way to the breakthrough in comparative linguistics in the first quarter of the nineteenth century. ${ }^{79}$ If we concluded earlier on that Reland was not far ahead of his time, then it is safe to say that this is at least partly the case for Wotton. Admittedly, Wotton was not the first scholar to underline the relevance of shared grammatical structures before one could claim genealogical kinship, ${ }^{80}$ but he was, to the best of my knowledge, the first to demonstrate its primordial importance. This is why it may come as a surprise that so far not more than a handful of historiographers have paid any attention to Wotton. It also needs to be stressed that Wotton's observations were more than an occasional argument developed in order to trump Reland's criticisms. In the first part of his work he had already attached great significance to this insight, which deserves an analysis in its own right. ${ }^{81}$ Reland,

\footnotetext{
$76 \quad$ Ibid., p. 59 .

77 Ibid., p. 6o.

78 Ibid.

79 See, for instance, A. Morpurgo Davies, 'Nineteenth-Century Linguistics'.

8o Van Hal, 'Moedertalen en taalmoeders', pp. 458-6o.

81 Wotton, Discourse, pp. 15-27. I am currently preparing a book which will devote a chapter to the increasing attention paid to grammatical similarities throughout the Early Modern period.
} 
in turn, had occasionally mentioned conjugations and inflections of some of the languages under investigation, but always against the background of the lexicon. ${ }^{82}$ Just like previous scholars, such as Goropius Becanus and Philippus Cluverius, ${ }^{83}$ Reland, for instance, selected the third person singular of the verb to be in order to make some comparative exercises, in his case between Hebrew, Persian, Greek and Dutch. ${ }^{84}$ It is important, however, to highlight the fact that these three scholars do not consider these similarities in a conjugational paradigm to be a special category in their argumentative strategy. In other words, any similarities in the conjugation are part and parcel of lexical parallels in general. ${ }^{85}$

The discussions between Wotton and Reland have thus shown how a literal reading of the Bible could still result in divergent and linguistically innovative ideas. More generally, we have seen how Reland, while elaborating on the thorough and lively discussion on language similarities in the Netherlands of the seventeenth century, also crucially contributed to refining a number of methodological principles. His untimely death, 300 years ago, prevented him from further developing his ideas, which were certainly in a state of flux.

\section{Bibliography}

\section{Sources}

Bibliander, Th., De ratione communi omnium linguarum et literarum commentarius [...], Zürich, C. Frosch[auer], 1548.

Cluverius, Ph., Germaniae antiquae libri tres [...], Leiden, Elzevier, 1616.

Cuper, G., Lettres de critique, de litterature, d'histoire, etc. escrites a divers savans de l'Europe, Amsterdam and Leipzig, Arkstee and Merkus, 1745.

Goropius Becanus, J., Opera hactenus in lucem non edita, nempe Hermathena, Hieroglyphica, Vertumnus, Gallica, Francica, Hispanica, Antwerp, Christoph Plantin, 1580 .

Hayne, Th., Linguarum cognatio seu De linguis. In genere et de variarum linguarum harmonia dissertatio, London, Whitaker, 1648.

Hooght, E. van der, Lexicon Novi Testamenti Graeco-Latino-Belgicum, seu Manuale Graecum Georgii Pasoris: nunc emendatum, in ordinem alphabeticum redactum,

82 E.g. Reland, 'Dissertatio de linguis Americanis', pp. 178-8o.

83 Goropius Becanus, Opera hactenus in lucem non edita, Herm., p. 66; Cluverius, Germaniae antiquae libri tres, pp. 73-74.

84 Reland, 'Dissertatio de linguis Americanis', p. 151.

85 On this tendency, see Auroux and Hordé, 'Les grandes compilations et les modèles de mobilité', p. 567 . 
quintupliciter auctum, et analysi omnium verborum, tyroni utcunque difficiliorum, locupletatum, Amsterdam, N. Wassenaar, 169 o.

Jaucourt, [Ch.] de, 'Ryp', in Encyclopédie ou Dictionnaire raisonné des Sciences, des Arts et des Métiers, D. Diderot and J. Le Rond d'Alembert (eds), Paris, Briasson et al., 1765, vol. 9, pp. 449-50.

Marsden, W., A Catalogue of Dictionaries, Vocabularies, Grammars, and Alphabets, London, [s.n.], 1796.

Polenus, J. (ed.), 'Gisberti Cuperi et Ottonis Sperlingii dissertationes, sive epistolae mutuae de variis rebus et quaestionibus quae pertinent ad antiquitates Graecas et Romanas nunc primum ex MSS. editae ex museo Jo. Grammii Hafniensis', in Utriusque thesauri antiquitatum Romanarum Graecarumque nova supplementa congesta, Venice, J.B. Pasquali, 1737, vol. 4, pp. 1-304.

Priestley, J., A Course of Lectures on the Theory of Language, and Universal Grammar, Warrington, W. Eyres, 1762.

[Reimarus, H.S.], 'Ein Mehreres aus den Papieren des Ungenannten, die Offenbarung betreffend: Zweytes Fragment:Unmöglichkeit einer Offenbarung, die alle Menschen auf eine gegründete Art glauben könnten', in G.E. Lessing (ed.), Zur Geschichte und Litteratur: Aus den Schätzen der Herzoglichen Bibliothek zu Wolfenbüttel, Braunschweig, Buchhandlung des Fürstl. Waysenhauses; Wolfenbüttel, Bindseil, 1777, pp. 288-365.

Reland, A., Dissertationum miscellanearum pars tertia, Utrecht, Willem Broedelet, 1708.

Reland, A., Oratio pro lingua Persica et cognatis litteris Orientalibus, Utrecht, Willem vande Water, 1701.

Reland, A., 'De reliquiis veteris linguae Persicae', in Dissertationum miscellanearum, vol. 2, Utrecht, Willem Broedelet, 1707, pp. 97-226.

Reland, A., 'Dissertatio de linguis Americanis', in Dissertationum Miscellanearum, vol. 3, Utrecht, Willem Broedelet, 1708, pp. 143-229.

Reland, A., 'Dissertatio de linguis insularum quarundam orientalium', in Dissertationum Miscellanearum, vol. 3, Utrecht, Willem Broedelet, 1708, pp. 55-139.

Robertson, W., An Historical Disquisition Concerning the Knowledge Which the Ancients Had of India: And the Progress of Trade with That Country Prior to the Discovery of the Passage to It by the Cape of Good Hope, London and Edinburgh, A. Strahan and T. Cadell, 1794.

Serrurier, J., Oratio funebris in obitum viri celeberrimi Hadriani Relandi, antiquitatum sacrarum et linguarum orientalium professoris ordinarii, recitata ipsis nonis Martiis MDCCXVIII, Utrecht, Willem vande Water, 1718.

Smith, J., The Generall Historie of Virginia, New-England, and the Summer Isles [...], London, E. Blackmore, 1632.

Valentijn, F., Oud en nieuw Oost-Indiën: vervattende een naaukeurige en uitvoerige verhandelinge van Nederlands mogentheyd in die gewesten ... 5 vols., Dordrecht and Amsterdam, Joannes van Braam and Gerard onder de Linden, 1724-1726. 
Valvasor, J.W. von, Deß Hochlöbichen Hertzogthums Crain Topographisch-Historischer Beschreibung [Buch $5^{-8}$ ], [Ljubljana and Nürnberg, W.M. Endter], 1689.

Walton, B., 'Prolegomenon I. De Linguarum natura, origine, divisione, numero, mutationibus, et usu', in Biblicus apparatus chronologico-topographico-philologicus. [...], Zürich, Ex Typographeo Bodmeriano, 1673, pp. 208-218.

Wiseman, N., 'Lecture the First; on the Comparative Study of Languages. Part 1', in idem, Twelve Lectures on the Connection between Science and Revealed Religion: Delivered in Rome, and edn., London, Charles Dolman, 1842, pp. 1-43.

Wotton, W., A Discourse Concerning the Confusion of Languages at Babel: Proving It to Have Been Miraculous, from the Essential Difference Between Them, Contrary to the Opinion of Mons. Le Clerc, and Others. With an Enquiry into the Primitive Language, Before That Wonderful Event, London, S. Austen and W. Bowyer, 1730.

Wotton[ius], W., 'Dissertatio de confusione linguarum Babylonica', in J. Chamberlayne (ed.), Oratio dominica in diversas omnium fere gentium linguas versa et propriis cujusque linguae characteribus expressa. Una cum dissertationibus nonnullis de linguarum origine variisque ipsarum permutationibus, Amsterdam, Willem and David Goerei, 1715 , pp. 37-75.

\section{Studies}

Anon., Report on the Manuscripts of His Grace the Duke of Portland:Preserved at Welbeck Abbey, Norwich, H.M. Stationery Office, 1899.

Auroux, S., and T. Hordé, 'Les grandes compilations et les modèles de mobilité', in S. Auroux (ed.), Histoire des idées linguistiques, 2: Le développement de la grammaire occidentale, Sprimont, Mardaga, 1992, pp. 538-579.

Bastiaensen, M., 'Adrien Reland à la recherche d'une méthode comparative', Histoire, Epistémologie, Langage, vol. 6, no. 2, 1984, pp. 45-54.

Bastiaensen, M., 'Adrien Reland et la justification des études orientales', Études sur le XVIII ${ }^{e}$ siècle, vol. 1, 1974, pp. 13-27.

Bruijn, J.T.P. de, De ontdekking van het Perzisch. Rede uitgesproken bij de aanvaarding van het ambt van bijzonder hoogleraar in de cultuurgeschiedenis van Iran sedert de opkomst van de islam aan de Rijksuniversiteit te Leiden op 9 maart 199o, Leiden, Rijksuniversiteit Leiden, 199 o.

Campbell, L., Historical Linguistics, 3rd edn., Edinburgh, Edinburgh University Press, 2013.

Carhart, M.C., Leibniz Discovers Asia: Social Networking in the Republic of Letters, Baltimore, Johns Hopkins University Press, 2019.

Carroll, D.J., 'William Marsden and Patterns of British Scholarship in the Malay Peninsula', Indonesia and the Malay World, vol. 39, no. 114, 2011, pp. 269-294. https:// doi.org/10.108o/13639811.2011.575623.

Considine, J., Small Dictionaries and Curiosity: Lexicography and Fieldwork in Post-Medieval Europe, Oxford, Oxford University Press, 2017. 
Donohue, M., and T. Denham, 'Farming and Language in Island Southeast Asia: Reframing Austronesian History', Current Anthropology, vol. 51, no. 2, 2010, pp. 223256. https://doi.org/10.1086/650991.

Gabelentz, G. von der, Die Sprachwissenschaft: Ihre Aufgaben, Methoden und bisherigen Ergebnisse, in J. McElvenny and M. Ringmacher (eds), Berlin, Language Science Press, 2016. https://doi.org/10.2653o/OAPEN_611696.

Groetsch, U., Hermann Samuel Reimarus (1694-1768): Classicist, Hebraist, Enlightenment Radical in Disguise, Leiden and Boston, Brill, 2015.

Hal, T. van, 'Leibniz, das Vaterunser und die Sprachvielfalt', in M. Grötschel et al. (eds), Vision als Aufgabe. Das Leibniz-Universum im 21. Jahrhundert, Berlin, BerlinBrandenburgische Akademie der Wissenschaften, 2016, pp. 255-264. https://lirias .kuleuven.be/retrieve/418222.

Hal, T. van, 'Moedertalen en taalmoeders'. Het vroegmoderne taalvergelijkende onderzoek in de Lage Landen, Verhandelingen Nieuwe Reeks, vol. 20, Brussel, Koninklijke Vlaamse Academie voor Wetenschappen en Kunsten, 2010. https://irias.kuleuven .be/retrieve $/ 253387$.

Lewis, G., The Turkish Language Reform: A Catastrophic Success, Oxford, Oxford University Press, 1999.

Li, W. (ed.), Einheit der Vernunft und Vielfalt der Sprachen-Beiträge zu Leibnizens Sprachforschung und Zeichentheorie, Studia Leibnitiana, vol. 38, Stuttgart, Steiner, 2014.

Melebek, A.R., Sejarah bahasa Melayu, Kuala Lumpur, Utusan Publications, 2006.

Meyers, C., Adrien Reland (1676-1718) linguiste et orientaliste: deux contributions à l'histoire de la philologie comparée, mA thesis, Université catholique de Louvain, 2019. http://hdl.handle.net/2078.1/thesis:20056, accessed 3 April 2021.

Morpurgo Davies, A., 'Nineteenth-Century Linguistics', in G. Lepschy (ed.), History of Linguistics, Vol. 4, London and New York, Longman, 1998.

Murray, L.J., 'Vocabularies of Native American Languages: A Literary and Historical Approach to an Elusive Genre', American Quarterly, vol. 53, no. 4, 2001, pp. 59o-623.

Nat, J., De studie van de oostersche talen in Nederland in de 18e en de rge eeuw, Purmerend, Muusses, 1929 .

Pawley, A., 'Nayacakalou Medal Address: Explaining the Aberrant Austronesian Languages of Southeast Melanesia: 15 O Years of Debate', The Journal of the Polynesian Society, vol. 115, no. 3, 2006, pp. 215-258.

Peters, M., 'From the Study of Nicolaes Witsen (1641-1717). His Life with Books and Manuscripts', Lias. Sources and Documents Relating to the Early Modern History of Ideas, vol. 21, 1994, pp. 1-47.

Pytlowany, A., and T. Van Hal, 'Merchants, Scholars and Languages. The Circulation of Linguistic Knowledge in the Context of the Dutch East India Company (VOC)', Histoire Épistémologie Langage, vol. 38, no. 1, 2016, pp. 19-38. http://dx .doi.org/10.1051/hel/2016380102. 
Raj, K., Relocating Modern Science: Circulation and the Construction of Knowledge in South Asia and Europe, 1650-1900, Houndmills and New York, Palgrave Macmillan, 2007 .

Reid, A., 'Indonesian Manuscripts in the Vatican Library', Southeast Asia Library Group Newsletter, vol. 46, 2014, pp. 51-6o.

Souza, T.C.C. de, 'Political and Linguistic Aspects of the History of Indigenous Linguistics in Brazil', in C. Assunção, G. Fernandes, and R. Kemmler (eds), Tradition and Innovation in the History of Linguistics. Contributions from the 13 th International Conference on the History of the Language Sciences (ICHoLS XIII), Vila Real, 25-29 August 2014, Münster, Nodus, 2016, pp. 356-364.

Tadmor, U., 'Loanwords in the World's Languages: Findings and Results', in M. Haspelmath and U. Tadmor (eds), Loanwords in the World's Languages: A Comparative Handbook, Berlin and New York, De Gruyter, 2009, pp. 55-75.

Zulaika Hernández, J.M., 'Nuevos datos sobre las obras vascas de Pierre d'Urte', Estudios de Lingüística de la Universidad de Alicante, vol. 23, 2009, pp. 315-35o.

Zwartjes, O., 'The Historiography of Missionary Linguistics: Present State and Further Research Opportunities', Historiographia Linguistica, vol. 39, nos. 2-3, 2012, pp. $185^{-242 .}$ 